\title{
The Morphology-Phonology Connection
}

\author{
SHARON INKELAS \\ University of California, Berkeley
}

\section{Introduction}

- Morphology: generalizations about form and meaning that relate words to one another within a language

- Phonology: generalizations about the sound patterns in that language

- The statement of many morphological generalizations includes information about sound patterns (realizational morphology); the statement of many phonological generalizations includes information about morphology (morphologically conditioned phonology), blurring the distinction between morphology and phonology in many situations.

- Three approaches relevant to this aspect of morphology-phonology interface:

○ Cophonology Theory (e.g. Orgun 1996, Inkelas 1998, Anttila 2002, 2007, 2008, 2009, Inkelas and Zoll 2005, 2007)

- Stratal Optimality Theory (e.g. Kiparsky 2000, 2003a, b, 2007, 2008)

- Indexed Constraint Theory (e.g. McCarthy and Prince 1995, Smith 1997, Kiparsky 2000, 2003a, b, Itô and Mester 1999, Alderete 2001, Pater 2000, 2009).

\section{Claim of paper}

The ideal theory will capture these generalizations:

SUBSTANCE: Morphologically conditioned phonology and realizational morphology involve the same operations

SCOPE: Morphologically conditioned phonology and realizational morphology have identical scope of application within a word

LAYERING: Morphologically conditioned phonology and realizational morphology are identical in their interactions in complex words

\section{Morphologically conditioned phonology (MCP)}

MCP: a particular phonological pattern is imposed on a proper subset of morphological constructions (affix, reduplication, compounding) and thus is not fully general in the lexical phonology of the language.

Example 1: Mam (Willard 2004, based on England 1983). 'Dominant' affixes cause long root vowels to shorten (1a); 'Recessive' suffixes preserve root vowel length (1b). Dominant vs. recessive status must be learned individually for each affix.

\begin{tabular}{|l|l|l|l|l|l|}
\hline a. & \multicolumn{5}{|l|}{ Dominant suffix: shortens long root vowel } \\
\hline & facilitative & liich'- & $\rightarrow$ & lich'-ich'iin & 'break/breakable' \\
\hline & resultant locative & juus- & $\rightarrow$ & jus-b'een & 'burn/burned place' \\
\hline & directional & jaaw- & $\rightarrow$ & jaw-nax & 'go up/up' \\
\hline & participial & nooj- & $\rightarrow$ & noj-na & 'fill/full' \\
\hline b. & Recessive suffix: preserves root vowel length & \\
\hline & \multirow{2}{*}{ intransitive verbalizer } & muq- & $\rightarrow$ & muq-oo & 'bury (n.)/bury (v.)' \\
\cline { 3 - 6 } & & b'iitz- & $\rightarrow$ & b'iitz-oo [b'liitza] & 'song/sing' \\
\hline & instrumental & luk- & $\rightarrow$ & luk-b'il & 'pull up/instr. for pulling up' \\
\hline & remainder & waa- & $\rightarrow$ & waa-b'an & 'eat/remains of food' \\
\hline
\end{tabular}


Example 2: Malayalam (Mohanan 1995:52). Gemination applies at the internal juncture of subcompounds (head-modifier) (b) but not at the internal juncture of cocompounds (coordinate) (c):

\begin{tabular}{|l|l|l|l|l|}
\hline a. & meeşa & 'table' & petti & 'box' \\
\hline & kasaala & 'chair' & -kalə & (plural suffix) \\
\hline b. & {$[\text { meeşa-ppetti }]_{\text {S }}$-kalə } & \multicolumn{2}{|l|}{ 'boxes made out of tables' } \\
\hline c. & {$[\text { meeşa-petti }]_{C}-$ kalə } & 'tables and boxes' \\
\hline
\end{tabular}

Example 3: English. Suffixes fall into two classes (e.g. Allen 1978, Siegel 1974, Chomsky and Halle 1968, Kiparsky 1982a):

\begin{tabular}{|l|l|l|}
\hline Base & Stress-shifting suffix & Non-stress-shifting suffix \\
\hline párent & parént-al & párent-ing \\
\hline président & prèsidént-ial & présidenc-y \\
\hline áctive & àctív-ity & áctiv-ist \\
\hline démonstràte & demonstrative & démonstràtor \\
\hline
\end{tabular}

Unifying thread: some morphological constructions in the language (affixation, compounding) are associated with a pattern that other constructions (other affixation, other compounding) are not.

\section{Realizational (process) morphology (RM)}

RM: a morphological category is exponed by a phonological process other than additive combination of phonologically contentful morphemes.

Example 1: Tohono O'odham (Yu 2000:129-30, citing Zepeda 1984; Anderson 1992, citing Zepeda 1983). Perfective verbs derived from imperfectives by deleting a final segment (or $\mathrm{V}_{[+\mathrm{hi}]} \mathrm{C}_{[+\mathrm{cor}]}$ ):

\begin{tabular}{|l|l|l|l|}
\hline Imperfective & Perfective & gloss & data source \\
\hline síkon & síko & 'hoe object' & Yu 2000 \\
\hline híwa & híw & 'rub against object' & Yu 2000 \\
\hline hínk & hi:n & 'bark' & Anderson 1992 \\
\hline
\end{tabular}

Example 2: Keley-i (Malayo-Polynesian; Samek-Lodovici 1992, citing Reid 1975, Schachter 1976, Hohulin \& Kenstowicz 1979). Nonperfect aspect marked by consonant gemination, providing a coda to what would otherwise be the leftmost light syllable (5a-c). Blocked in words with all closed (heavy) syllables (5d, object and subject focus):

(5)

\begin{tabular}{|c|c|c|c|c|c|}
\hline & & (a) & (b) & (c) & (d) \\
\hline & Base: & pili & duyag & Pagtu & duntuk \\
\hline \multirow{3}{*}{ 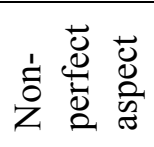 } & Object focus: & pilli & duyyag & Pagtu & duntuk \\
\hline & Access. focus: & Pi-ppili & Pi-dduyag & Pi-P?agtu & Pi-dduntuk \\
\hline & Subject focus: & um-pilli & um-duyyag & man-Pagtu & um-duntuk \\
\hline
\end{tabular}

Example 3: English (e.g. Kiparsky 1982b). Stress shift marks the conversion from verbs to nouns.

\begin{tabular}{|l|l|l|}
\hline condúct & $\rightarrow$ & cónduct \\
\hline abstráct & $\rightarrow$ & ábstract \\
\hline recórd & $\rightarrow$ & récord \\
\hline
\end{tabular}


Unifying thread: a non-additive phonological process is the only systematic distinguishing marker of a morphological operation

5 Sketches of three approaches to morphologically conditioned phonology

Three theories designed to cover morphologically conditioned phonology, presented, for maximum comparative effect, in their strictest versions, ignoring nuanced variations of each.

5.1 Cophonology theory (e.g. Anttila 2002, 2007, 2008, Inkelas 1998, Inkelas et al. 1997, Inkelas and Zoll 2005, 2007, Orgun 1996)

- A member of the family of construction grammar theories (e.g. Goldberg 2006, Koenig 1999, Riehemann 1998, Booij to appear)

- The morphological grammar consists of a set of word-building constructions, each embodying both a meaning function (inflectional, derivational, the identity function) and a form function or 'cophonology', e.g. a set of ordered phonological rules or ranked constraints.

Example: -ify construction in English. $f(x)$ cophonology concatenates input stem with string -ify and performs (re)syllabification, stress shift, Trisyllabic laxing, velar softening:

$$
[\text { Phon }=\mathrm{f}(\mathrm{x})]
$$

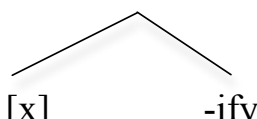

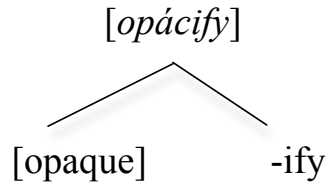

ify

- Each individual morphological construction has its own, potentially unique, cophonology. Comparative -er is associated with a cophonology that is stress-preserving (not stress-shifting), requires roughly monosyllabic inputs, and does not trigger Trisyllabic laxing or velar softening.

- Precedents for affix-specific cophonologies: Poser 1984, Bochner 1992.

- Similarities across cophonologies in a language are captured with meta-generalizations formalized as a 'grammar lattice' in Anttila 1997, 2002, 2007, 2008.

5.2 Stratal Optimality Theory (Stratal OT; Kiparsky 2000, 2003a, b, 2007, 2008)

- Descended from Lexical Morphology and Phonology (LMP; Kiparsky 1982a, b, 1984, 1985)

- Every language has three strata, each with its own phonological system:

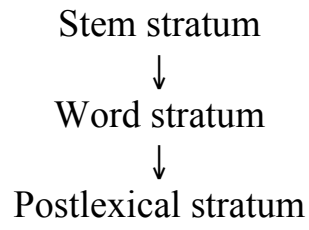

- Phonological differences between -ify and -er would be modeled by assigning -ify to the Stem stratum, which imposes resyllabification, stress shift, Trisyllabic laxing and velar softening, and er to the Word stratum, which imposes only resyllabification.

- Stratal OT $=$ a restrictive version of cophonology theory in which every morphological construction is associated either with the 'Stem' or the 'Word' cophonology. 
5.3 Indexed constraint theory (e.g. McCarthy and Prince 1995; Smith 1997, Itô and Mester 1999; Pater 2000, 2006, 2009; and Alderete 2001)

- Cophonology theory and Stratal OT: a language can have multiple grammars

- Indexed Constraint theory: each language has a single phonological grammar, but with morphologically indexed constraints. (Resembles The Sound Pattern of English (Chomsky \& Halle 1968), with a single grammar containing minor rules.)

- MCP: handled by indexing constraints to individual morphological contexts, e.g Max- $\mathrm{C}_{\text {root, }}$ Max- $\mathrm{C}_{\text {affix }}$, Max- $\mathrm{C}_{\mathrm{BR}}$, Align-stress-ity, etc.

Example: Assamese (Pater 2009, citing Mahatma to appear). [i] and [u] trigger regressive ATR harmony. With some [i]-initial suffixes, [a] is opaque; with others, [a] raises to +ATR [o] (or [e]):

\begin{tabular}{lllll}
{$[$ kopah $]$} & $\begin{array}{l}\text { 'cotton' } \\
\text { 'sokar] }\end{array}$ & $\begin{array}{l}\text { [kopahi] } \\
\text { [zokari] }\end{array}$ & $\begin{array}{l}\text { 'made of cotton' } \\
\text { 'shake (infinitive)' }\end{array}$ & suffix /-i/ \\
\hline [sal] & 'roof' & {$[$ soliya] } & 'roof' & suffix /-iya/ \\
{$[$ kopal] } & 'destiny' & {$[$ kopoliya] } & 'destined' &
\end{tabular}

Next: test Cophonology, Stratal OT, Indexed constraint theories against three generalizations about RM and MCP: SUBSTANCE, SCOPE and LAYERING

6 SUBSTANCE: Realizational morphology and morphologically conditioned phonology overlap substantively to the point of being essentially indistinguishable.

\subsection{Segment deletion}

- RM in Tohono O'odham (4): final segment deletion marks perfective in verbs.

- RM in Lardil: final vowel deletion marks nominative case in Lardil (Blevins 1997:249, citing original sources):

(9)

\begin{tabular}{|l|l|l|}
\hline NonFuture Accusative & Nominative & gloss \\
\hline kentapal-in & kentapal & 'dugong' \\
\hline ngaluk-in & ngalu & 'storey' \\
\hline mayarra-n & mayarr & 'rainbow' \\
\hline mela-n & mela & 'sea' \\
\hline
\end{tabular}

- MCP in Turkish: vowel hiatus arising at morpheme boundaries is repaired in most cases by glide epenthesis, but in one case - that of the progressive suffix -Iyor -by vowel deletion:

\begin{tabular}{|l|l|l|l|l|}
\cline { 2 - 5 } \multicolumn{1}{c|}{} & \multicolumn{2}{c|}{ C-final root } & \multicolumn{2}{c|}{ V-final root } \\
\cline { 2 - 5 } \multicolumn{1}{c|}{} & 'do' & 'come' & 'understand' & 'say' \\
\cline { 2 - 5 } & yap & gel & anla & söyle \\
\hline Facilitative/-Iver/: & yap-1ver & gel-iver & anla-yıer & söyle-yiver \\
\hline Progressive/-Iyor/: & yap-1yor & gel-iyor & anl-1yor & söyl-üyor \\
\hline
\end{tabular}

\subsection{Gemination}

- $\quad \mathrm{RM}$ in Keley-i: marks nonperfect aspect in verbs (5)

- MCP in Malayalam: phonological accompaniment to subordinate compounding (2)

- RM in Woleaian: stem-initial C gemination forms denotatives (Kennedy 2003:174)

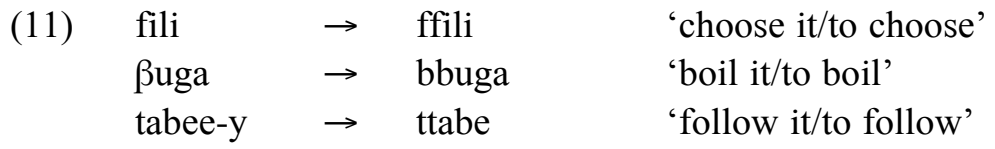


- MCP in Hausa (Newman 2000:235, 425): prefixing pluractional verb reduplication includes a process of stem-initial gemination that other prefixing reduplication constructions do not exhibit:

$\begin{array}{llll}\text { búgà: } & \rightarrow & \text { búbbúgà: } & \text { 'beat' } \\ \text { dánnè: } & \rightarrow & \text { dáddànné: } & \text { 'press down, oppress' } \\ \text { gyà:rú } & \rightarrow & \text { gyàggyàrrú } & \text { 'be well repaired' }\end{array}$

\subsection{Truncation to a prosodic constituent}

RM in Spanish (Pineros 2000:71): forms nicknames

$\begin{array}{lll}\text { Ricardo } & \rightarrow & \text { Rica } \\ \text { Armando } & \rightarrow & \text { Arma } \\ \text { Jesus } & \rightarrow & \text { Jesu } \\ \text { Concepción } & \rightarrow & \text { Conce }\end{array}$

MCP in Swedish (Weeda 1992:121, citing original sources): accompanies affixation in nicknames:
a. alkoholist $\rightarrow$ alk-is 'alcoholic' laboratori:um $\rightarrow$ labb-is 'lab'
b. mats $\rightarrow$ matt-e (proper name)
fabian $\quad \rightarrow$ fabb-e $\quad$ (proper name)

\subsection{Dissimilation and 'exchange' rules}

Dissimiliation: segment surfaces with value opposite to that of another segment in the same word (syntagmatic)

Exchanges/toggles: segment surfaces with value opposite to that of its own input value (paradigmatic) (see survey in Kurisu 2001).

- RM in Nuer (Frank 1999): input/ouput vowel length dissimilation marks the singular/plural distinction in some nouns:

(15)

\begin{tabular}{|l|l|l|l|}
\hline & Nominative singular & Nominative plural & gloss \\
\hline a. & ley & leey & 'animal(s)' \\
\hline & wuk & wuok & '(upper) arm(s)' \\
\hline b. & kaat & kât & 'vulture(s)' \\
\hline & yieer & yiër & 'river(s)' \\
\hline
\end{tabular}

- MCP in Hausa (Newman 2000:160ff., 598): 'stabilizer' clitics have a fixed segmental component (ne: for masculine, $c e$ : for feminine) but exhibit tone polarity relative to the preceding syllable:

(16)

\begin{tabular}{|l|l|l|l|}
\hline ...L-H & & ...H-L & \\
\hline gwàdò né: & 'it's a blanket' & kè:ké nè: & 'it's a bicycle' \\
\hline zó:bè: né: & 'it's a ring' & nán nè: & 'it's there (by you)' \\
\hline mó:tà: cé: & 'it's a car' & ákwálá: cè: & 'it's a piece of junk' \\
\hline gó:nâ-ř cé: & 'it's the farm' & rì̀gá: cè: & 'it's a gown' \\
\hline
\end{tabular}

\subsection{Stress/pitch-accent (re)assignment}

- RM in English: verb-to-noun conversion in (6)

- MCP in English: stress-neutral vs. stress-shifting suffixes (3) 


\subsection{Review:}

- The phonological operations used in RM are essentially the same operations that, as MCP, can accompany overt affixation, reduplication and compounding (cf. Anderson 1975)

- Practical criterion (used above): a phonological alternation is classified as RM if it is the sole exponent of a morphological construction, but as MCP if it accompanies what is judged to be the primary exponent of a morphological construction (affixation, reduplication, compounding).

\section{Duplication Problem}

- In many cases it is difficult or impossible or pointless to determine whether a given phonological effect is primary $(\mathrm{RM})$ or secondary $(\mathrm{MCP})$.

(17) Hausa (Newman 2000). Tone replacement is RM in (17a) but RCP in (17c):

\begin{tabular}{|l|l|l|}
\hline & base tone replaced & base tone preserved \\
\hline zero derivation & $\checkmark$ & $\checkmark$ \\
\hline overt affixation & $\checkmark$ & $\checkmark$ \\
\hline
\end{tabular}

a. No affixation; tone replacement (imperative formation)

$\begin{array}{lll}\text { ká:mà: } & \rightarrow \text { kà:má: } & \text { 'catch (!)’ } \\ \text { bíncìké: } & \rightarrow \text { bìncìké: } & \text { 'investigate }(!) ' \\ \text { nánné:mó: } & \rightarrow \text { nànnè:mó: } & \text { 'seek repeatedly }(!) ’ \text { (< né:mó: 'seek') }\end{array}$

b. No affixation, no tone replacement (Grade 2 verbal noun formation)

$\begin{array}{lll}\text { fânsá: } & \rightarrow \text { fànsá: } & \text { 'redeem/redeeming' } \\ \text { tàmbáyà: } & \rightarrow \text { tàmbáyà: } & \text { 'ask/asking' }\end{array}$

c. Overt affixation, tone replacement (various plural classes)

má:làm $\rightarrow$ màlàm-ái 'teacher-pl' $\quad-\mathrm{LH}$

rì̀gá: $\quad \rightarrow$ rí:g-únà: $\quad$ 'gown-pl' $\quad$-HL

tàmbáyà: $\rightarrow$ támbáy-ó:yí: $\quad$ 'question-pl' $-\mathrm{H}$

d. Overt suffixation, no tone replacement (various)

\begin{tabular}{|c|c|c|c|c|}
\hline dáfâ: & $\rightarrow$ dáfâ:-wá & 'cook-ppl' & $-\mathrm{LH}$ & \\
\hline & $\rightarrow$ gàjé:r-ìyá: & 'short-fem' & $-\mathrm{LH}$ & \\
\hline bỳýr & $\rightarrow$ hù̀lâ-r̆ & 'hat-def' & $-\mathrm{L}$ & {$[\check{r}]=$ trill, $[\mathrm{r}]=$ approximant } \\
\hline
\end{tabular}

Paradox: Barasana mutual blocking (Pycha 2005, citing Gomez-Imbert and Kenstowicz 2000). Some Barasana suffixes affect stem tone. Non3rdSubj suffix - $b \dot{i}$ causes $H$ tone to align all the way to the right in words containing it; Interrogative suffix -ri causes $\mathrm{H}$ to align all the way to the left

\begin{tabular}{|c|l|}
\hline $\begin{array}{c}\text { baa-bi } \\
\text { HH H }\end{array}$ & 'swim-Non3rdSubj = I/you/we swim' \\
\hline $\begin{array}{c}\text { baa-ri } \\
\text { H }\end{array}$ & 'swim-Interrogative = did he/she/they swim?' \\
\hline
\end{tabular}

Mutual blocking (Pycha 2005): The segmental components of Non3rdSubj and Interrogative cannot co-occur (18a), nor can their mutually incompatible effects on tone both be realized. In words where both meanings are desired, we find the segments of the Interrogative -- and the tones of the Non3rdSubj (18b):
a. *baa-ri-bi, *baa-bi-ri
'did I/you/we swim?'
b. baa-ri
'did I/you/we swim?'
$\mathrm{HH} \mathrm{H}$ 
- Pycha: in (18), both Non3rdSubj, Interrogative achieve exponence, by using the segments of one and the cophonology of the other.

- Paradox: The tone of Non3rdSubject is RM when co-occurring with the Interrogative but MCP otherwise.

- Desired solution: somehow reduce both RM and MCP to the same formalism, even if for convenience they continue to be distinguished terminologically. Earlier work advocating this position: Anderson 1992, Bochner 1992, Dressler 1985, Ford and Singh 1983, 1985, Poser 1984, Singh 1987, 1996).

\section{Theoretical discussion}

How do Cophonology Theory, Indexed Constraint Theory and Stratal OT model RM and MCP?

7.1 Cophonology theory uses the same mechanism to account for so-called RM and so-called MCP.

Example: English truncation is modeled by a cophonology $g(x)$ which maps an input to an output of a certain size, e.g. two syllables.

$g(x)$ : a cophonology limiting the output to two syllables ( $\sigma \sigma>>$ Max)

\section{Truncation as RM}<smiles>CC(=O)OC(=O)OC(=O)OC(=O)O</smiles>

(Realizational morphology)

\section{Truncation as MCP}

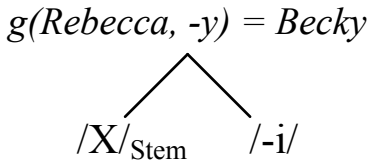

(Morphologically conditioned phonology)

7.2 Indexed Constraint Theory: all phonological alternations are accomplished by the ranking of phonological constraints. Expectation: Indexed Constraint theory should make essentially the same predictions as in cophonology theory regarding the substance of realizational morphology and morphologically conditioned phonology.

Kurisu 2001: REALIZE-MORPH (indexed to particular morphemes) is a source of RM. REALIZE-MORPH requires that the phonological output of a morphological construction be non-homophonous with the input. REALIZE-MORPH requires a construction with no overt affix to undergo some phonological change, to be determined by the ranking of markedness and faithfulness constraints of the grammar. Icelandic: deverbal nouns are formed by deleting the final vowel from the infinitive:

$$
\begin{array}{lll}
\text { klifra } & \rightarrow \text { klifr } & \text { 'climb/climbing' } \\
\text { grenja } & \rightarrow \text { grenj } & \text { 'cry/crying' } \\
\text { söötra } & \rightarrow \text { söötr } & \text { 'sip/sipping' } \\
\text { puukra } & \rightarrow \text { puukr } & \text { 'conceal/concealment' }
\end{array}
$$

Dep, RM » Max; the need to satisfy RM compels a Max violation.

\begin{tabular}{|l|l||c:c|c|}
\hline & /klifra/ & RM & DEP & MAX \\
\hline \hline a. & klifra & $!^{*}$ & & \\
\hline b. & klifr & & & $*$ \\
\hline c. & klifrata & & $* !$ & \\
\hline
\end{tabular}


REALIZE-MORPH = indexed constraint, like Faith-BR (McCarthy \& Prince 1995), Faith-Noun (Smith 1997, 1998, 2001), etc.

7.3 Stratal OT: has little to say about RM or its relation to MCP. Suited for generalizations holding over stems and words, not construction-specific alternations. As not all stem morphology in English is truncating, Stratal OT cannot identify the truncation in Rebecca $\rightarrow$ Becca with Stem phonology. Requires supplementation with indexed constraints or cophonologies, thus merging with the other approaches.

\section{SCOPE}

RM and MCP: the scope of the phonological effect(s) is the stem produced by the word formation process in question.

Cophonology Theory: the scope of each cophonology is the morphological subconstituent built by the associated construction.

Example: in a word with three suffixes, cophonology theory predicts that the cophonology of Stem2 can affect the surface form of Stem1 and Suffix2, but that the cophonology of Stem2 cannot affect the surface form of Suffix 3

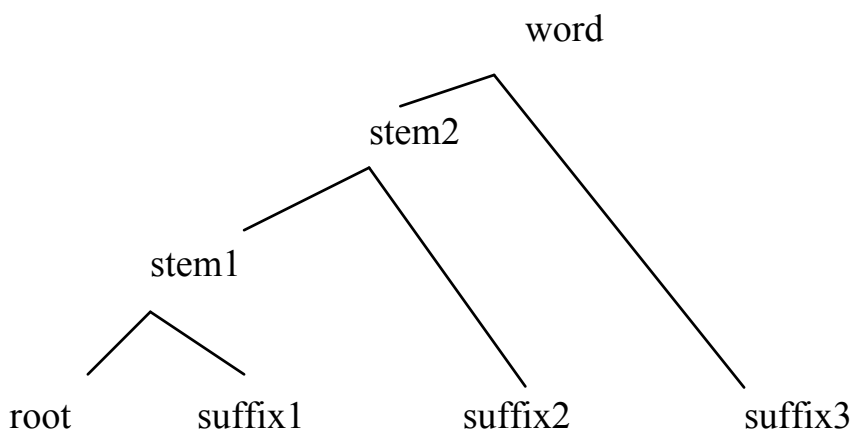

(24) Hausa ventive construction is tone-replacing (Newman 2000:663), e.g. fitá: (LH) 'go out' $\rightarrow$ fit-ó: $(\mathrm{H})$ 'come out'. Verbal noun former is tone-preserving (- 'wá). Ventive can be converted to verbal noun. Ventive cophonology has scope only over ventive stem.

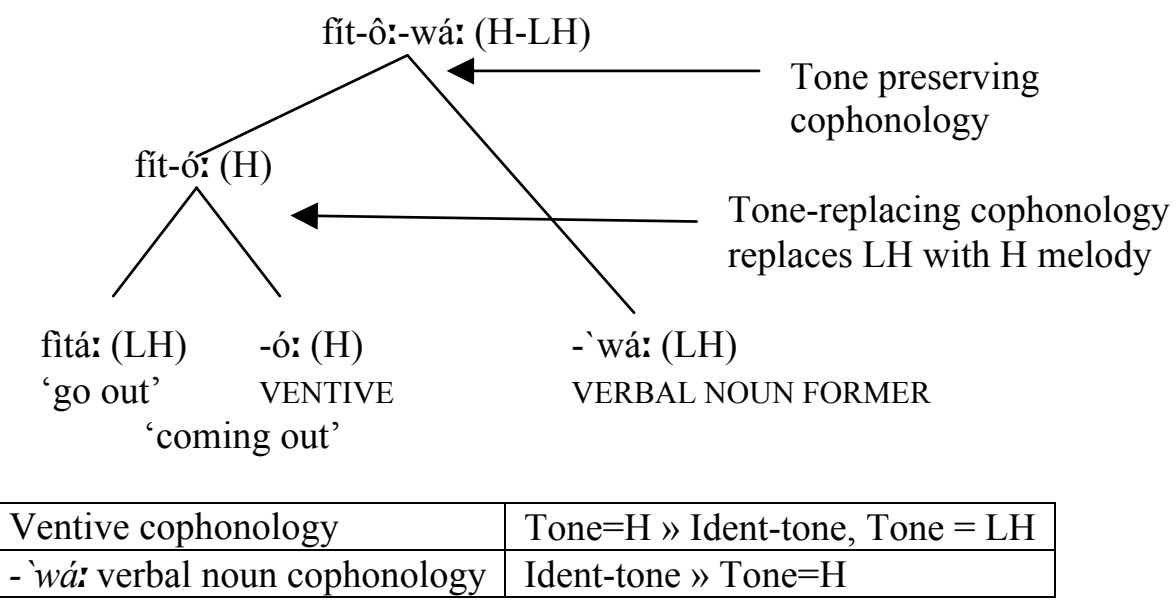

Scope effects of this kind are an intrinsic prediction of cophonology theory. 
Stratal OT makes correct scope predictions for effects in different strata (Word has scope over Stem, but not vice versa), but has trouble with effects that are not general within Stems or Words.

Hausa in Stratal OT: tone replacement $=$ Stem-level; tone-preservation $=$ Word-level. Works for (24). Problem: tone-replacement and tone-preservation are not stratally ordered:

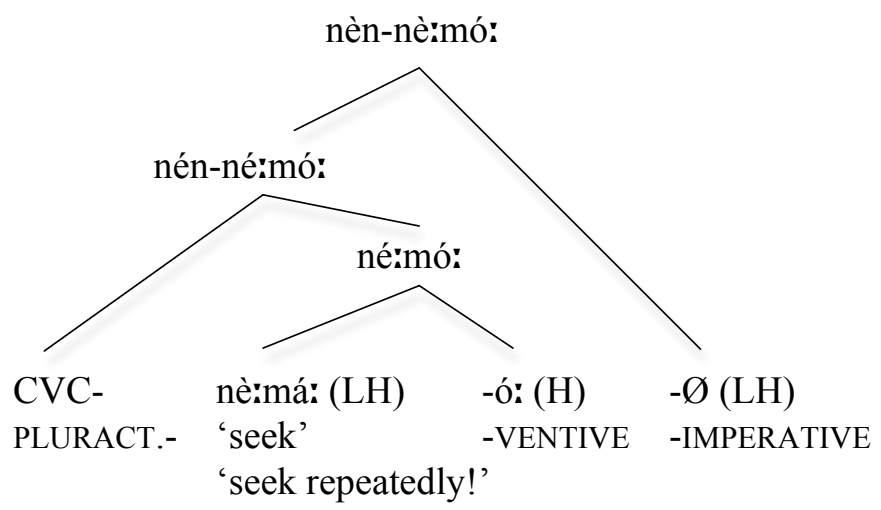

Because Words and Stems are strictly ordered, Stratal OT strictly speaking cannot handle this case.

Indexed constraint theory: one constraint ranking for the entire language. The cophonologies in (24) can translate into indexed constraints (on what constraints can be indexed, see e.g. Ito \& Mester 1999, Alderete 2001, Inkelas \& Zoll 2007, Pater 2009)
a. Ident-tone- ${ }^{\text {wá: }}$ » Tone $=\mathrm{H} \gg$ Ident-tone
b. Tone $=\mathrm{H}_{\text {Ventive }} »$ Ident-tone $»$ Tone $=\mathrm{H}$

What are constraints indexed to? Tone $=\mathrm{H}_{\text {Ventive }}$ must refer to the entire ventive stem, not just the ventive suffix -ó:, to generate nè:má: $\rightarrow$ né:mó:. To capture SCOPE, recent work in Indexed Constraint theory has moved toward cophonology theory by indexing constraints to stems, not morphemes (e.g. Alderete 2001).

\section{Layering}

- A corollary of the scopal prediction of cophonology theory

- The effect in which, given a structure where $X$ is a daughter of $Y$, the output of the cophonology associated with $\mathrm{X}$ is the input to the cophonology of $\mathrm{Y}$.

(27) Two tone-replacing cophonologies:

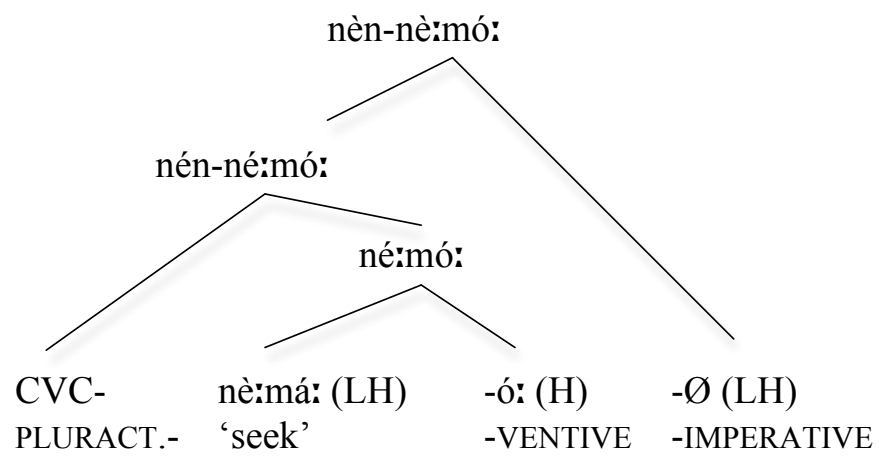

The way two cophonologies in the same word interact depends intrinsically on the hierarchical structure of the word. The outer construction has the last say. 
Stratal Optimality Theory: predicts layering (Kiparsky 2000: all opacity results from layering). Problem for Stratal Optimality Theory: not enough layers.

Indexed Constraint Theory: does not predict layering. Interactions between different RM/MCP effects follow from constraint ranking, fixed in the grammar, and not from constituent structure. Recursion is not possible.

Example: Hausa word with two tone-replacing constructions. Ventive inside Imperative. LH imperative melody takes precedence over ventive melody, because Tone- $\mathrm{LH}_{\text {Imper }} \gg$ Tone $=\mathrm{H}_{\text {Vent }}$ :

\begin{tabular}{|c|l||c|c|c|}
\hline & {$\left[[\text { nè:má: -ó: }]_{\text {Ventive_ }} \varnothing\right]_{\text {Imper. }}$} & TONE $=\mathrm{LH}_{\text {Imper. }}$ & TONE$=\mathrm{H}_{\text {Vent }}$ & IDENT \\
\hline \hline a. & né:mó: & $* !$ & $*$ & $*$ \\
\hline b. & nè:mó: & & $*$ & \\
\hline
\end{tabular}

- What if the morphology were recursive and the Ventive could occur outside the Imperative? Indexed Constraint theory predicts the same result: LH. Cophonology theory predicts the opposite result: $\mathrm{H}$.

- There are numerous languages in which the same constructions can occur in either order, with different phonological results. Mohanan 1986: two types of compounds in Malayalam can embed inside each other. Turkish: compounding, suffixation can occur in either order (Inkelas and Orgun 1998). Cibemba: derivational suffixes can combine in either order (Hyman 1992, 1994), etc. Indexed Constraint Theory does not capture the overarching generalization that scope is related to hierarchical position.

\section{Conclusion}

- Cophonology theory has a clear advantage in capturing SUBSTANCE, SCOPE, and LAYERING.

- Concern about cophonology proliferation: without a lid on cophonology variability, a language might vary as much internally as unrelated languages can vary (see e.g. Benua 1997a, b). Two responses (Inkelas and Zoll 2007, Pater 2009). (a) Formal. Anttila (1997, 2002, 2007): cophonologies in a same language conform to a partial master ranking of constraints; only constraints left unranked in this master ranking are allowed to vary in their ranking across individual cophonologies. (b) Substantive. Bermudez-Otero and McMahon (2006): cophonological diversity arises from diachronic change; languages change too slowly and systematically to produce wildly divergent cophonologies.

- Cophonology theory, Stratal OT and Indexed Constraint theory are already converging; their successor will share the common goal of tying morphologically conditioned phonological effects to morphological subconstituents of complex words.

\section{References}

Alderete, John. 2001. Dominance effects as transderivational anti-faithfulness. Phonology 18:201-253.

Allen, Margaret. 1978. Morphological investigations. Massachusetts Institute of Technology dissertation.

Anderson, Stephen R. 1975. On the interaction of phonological rules of various types. Journal of Linguistics 11:3963.

Anderson, Stephen R. 1992. A-morphous morphology. Cambridge: Cambridge University Press.

Anttila, Arto. 2002. Morphologically conditioned phonological alternations. Natural Language and Linguistic Theory 20:1-42.

Anttila, Arto. 2007. Variation and optionality. The Cambridge Handbook of Phonology, ed. by P. De Lacy, Cambridge: Cambridge University Press. 519-536. 
Anttila, Arto. 2008. Gradient phonotactics and the complexity hypothesis. Natural Language and Linguistic Theory 24:695-729.

Anttila, Arto. 2009. Derived environment effects in Colloquial Helsinki Finnish. The nature of the word: essays in honor of Paul Kiparsky, ed. by K. Hanson and S. Inkelas, Cambridge: MIT Press.

Benua, Laura. 1997a. Affix classes are defined by faithfulness. University of Maryland Working Papers in Linguistics 5:1-26.

Benua, Laura. 1997b. Transderivational Identity: Phonological Relations Between Words. University of Massachusetts dissertation.

Bermudez-Otero, Ricardo, and April Mcmahon. forthcoming. English phonology and morphology. The handbook of English linguistics, ed. by B. Aarts and A. McMahon, Oxford: Blackwell.

Blevins, Juliette. 1997. Rules in Optimality Theory: two case studies. Derivations and constraints in phonology, ed. by I. Roca, Oxford: Clarendon Press. 227-260.

Bochner, Harry. 1992. Simplicity in generative morphology: Publications in Linguistic Sciences 37. Berlin: Walter de Gruyter.

Booij, Geert. to appear. Construction morphology and compounding. The Oxford Handbook of Compounding, ed. by R. Lieber and P. Stekauer, Oxford: Oxford University Press.

Chomsky, Noam, and Morris Halle. 1968. The sound pattern of English. New York: Harper and Row.

Dressler, Wolfgang. 1985. Morphonology, the dynamics of derivation. Ann Arbor: Karoma Publishers.

England, Nora. 1983. A Grammar of Mam. Austin: University of Texas Press.

Ford, Alan, and Rajendra Singh. 1983. On the status of morphophonology. Papers from the parasession on the interplay of phonology, morphology and syntax, ed. by J. F. Richardson, M. Marks and A. Chukerman, Chicago: Chicago Linguistic Society. 63-78.

Ford, Alan, and Rajendra Singh. 1985. Towards a non-parametric morphology. Papers from BLS 11, ed. by M. Niepokuj, M. VanClay, N. Nikiforidou and D. Feder, Berkeley: Berkeley Linguistic Society. 87-95.

Frank, Wright. J. 1999. Nuer noun morphology. MA thesis, University of New York at Buffalo.

Gomez-Imbert, Elsa , and Michael Kenstowicz. 2000. Barasana tone and accent. International Journal of American Linguistics 66:419-463.

Hyman, Larry M. 1992. Velar palatalization in Cibemba: a "non-duplication" problem. Linguistique africaine 8:5571.

Hyman, Larry M. 1994. Cyclic phonology and morphology in Cibemba. Perspectives in phonology, ed. by J. Cole and C. Kisseberth, Stanford: CSLI Publications. 81-112.

Inkelas, Sharon. 1998. The theoretical status of morphologically conditioned phonology: a case study from dominance. Yearbook of Morphology 1997:121-155.

Inkelas, Sharon, and Cemil Orhan Orgun. 1998. Level (non)ordering in recursive morphology: evidence from Turkish. Morphology and its relation to phonology and syntax, ed. by S. Lapointe, D. Brentari and P. Farrell, Stanford, CA: CSLI Publications. 360-392.

Inkelas, Sharon, Cemil Orhan Orgun, and Cheryl Zoll. 1997. Implications of lexical exceptions for the nature of grammar. Constraints and Derivations in Phonology, ed. by I. Roca, Oxford: Clarendon Press. 393-418.

Inkelas, Sharon, and Cheryl Zoll. 2005. Reduplication: doubling in morphology: Cambridge University Press.

Inkelas, Sharon, and Cheryl Zoll. 2007. Is Grammar Dependence Real? A comparison between cophonological and indexed constraint approaches to morphologically conditioned phonology. Linguistics 45:133-171.

Itô, Junko, and Armin Mester. 1999. The phonological lexicon. The handbook of Japanese linguistics, ed. by N. Tsujimura, Malden, MA: Blackwell. 62-100.

Kennedy, Robert. 2003. Confluence in phonology: evidence from Micronesian reduplication. University of Arizona dissertation.

Kiparsky, Paul. 1982a. Lexical morphology and phonology. Linguistics in the morning calm, ed. by I.-S. Yang, Seoul: Hanshin. 3-91.

Kiparsky, Paul. 1982b. Word-formation and the lexicon. 1982 Mid-America linguistics conference papers, ed. by F. Ingemann, Lawrence, Kan: University of Kansas.

Kiparsky, Paul. 1984. On the lexical phonology of Icelandic. Nordic prosody II: papers from a symposium, ed. by C.-C. Elert, I. Johansson and E. Strangert, Umeå: University of Umeå. 135-162.

Kiparsky, Paul. 1985. Some consequences of lexical phonology. Phonology Yearbook 2:82-138.

Kiparsky, Paul. 2000. Opacity and cyclicity. The Linguistic Review 17:351-367.

Kiparsky, Paul. 2003a. Fenno-Swedish Quantity: Contrast in Stratal OT. Stanford University, ms. 
Kiparsky, Paul. 2003b. Finnish noun inflection. Generative approaches to Finnic and Saami linguistics, ed. by D. Nelson and S. Manninen, Stanford: CSLI Publications.

Kiparsky, Paul. 2007. Reduplication in Stratal OT. Stanford University ms.

Kiparsky, Paul. 2008. Compensatory lengthening. Stanford University ms.

Kurisu, Kazutaka. 2001. The phonology of morpheme realization. UC Santa Cruz dissertation.

Mccarthy, John, and Alan Prince. 1995. Faithfulness and reduplicative identity. University of Massachusetts Occasional Papers in Linguistics 18: Papers in Optimality Theory, ed. by J. Beckman, L. Dickey and S. Urbanczyk, Amherst, MA: GLSA. 249-384.

Mohanan, K. P. 1986. Lexical phonology. Dordrecht: Kluwer.

Mohanan, K. P. 1995. The organization of the grammar. The handbook of phonological theory, ed. by J. Goldsmith, Cambridge, MA: Blackwell Publishers. 24-69.

Newman, Paul. 2000. The Hausa language: an encyclopedic reference grammar. New Haven: Yale University Press.

Orgun, Cemil Orhan. 1996. Sign-based morphology and phonology: with special attention to Optimality Theory. University of California, Berkeley dissertation.

Pater, Joe. 2000. Non-uniformity in English secondary Stress: the role of ranked and lexically specific constraints. Phonology 17:237-274.

Pater, Joe. 2009. Morpheme-specific phonology: constraint indexation and inconsistency resolution. Phonological argumentation: essays on evidence and motivation, ed. by S. Parker, London: Equinox.

Pineros, Carlos-Eduardo. 2000. Prosodic and segmental unmarkedness in Spanish truncation. Linguistics 38:63-98.

Poser, William J. 1984. The phonetics and phonology of tone and intonation in Japanese. Massachusetts Institute of Technology dissertation.

Pycha, Anne. 2005. Partial Blocking. Paper presented at 41st Regional Meeting of the Chicago Linguistic Society

Samek-Lodovici, Vieri. 1992. A unified analysis of crosslinguistic morphological gemination. Proceedings of CONSOLE-1, Utrecht.

Siegel, Dorothy. 1974. Topics in English morphology. Massachusetts Institute of Technology dissertation.

Singh, Rajendra. 1987. Well-formedness conditions and phonological theory. Phonological 1984, ed. by W. Dressler, et al., Cambridge: Cambridge University Press.

Singh, Rajendra. 1996. Natural phono(morpho)logy: a view from the outside. Natural phonology: the state of the art. Papers from the Bern Workshop., ed. by B. Hurch and R. Rhodes, Berlin: Mouton.

Smith, Jennifer. 1997. Noun faithfulness: on the privileged status of nouns in phonology. ROA \# 242-1098.

Smith, Jennifer. 1998. Noun faithfulness and word stress in Tuyuca. Proceedings of ESCOL 97, ed. by J. Austin and A. Lawson, Ithaca: CLC Publications. 180-191.

Smith, Jennifer. 2001. Lexical category and phonological contrast. Papers in experimental and theoretical linguistics 6: Workshop on the lexicon in phonetics and phonology, ed. by R. Kirchner, J. Pater and W. Wikely, Edmonton: University of Alberta. 61-72.

Weeda, Donald Stanton. 1992. Word truncation in prosodic morphology. University of Texas, Austin dissertation.

Willard, E. Rainbow. 2004. Dominance effects in a dialect of Mam Maya. Paper presented at Linguistic Society of America annual meeting, Boston.

Yu, Alan C.-L. 2000. Stress Assignment in Tohono O'odham. Phonology 17:117-135.

Zepeda, Ofelia. 1983. A Papago grammar. Tucson: University of Arizona Press.

Zepeda, Ofelia. 1984. Topics in Papago morphology. University of Arizona dissertation.

Department of Linguistics

University of California

Berkeley, CA 94720-2650

inkelas@berkeley.edu 